\title{
The Effect of Facebook Use on Life Satisfaction and Subjective Happiness of College Students
}

\author{
Dr. Akanksha Srivastava ${ }^{1}$
}

\section{ABSTRACT}

The aim of the present investigation was to study the effect of Facebook uses on life satisfaction and subjective happiness of college students. 150 \{75 male and 75 female $\}$ college students age ranged 16-30 from Lucknow city of Uttar-Pradesh were selected through purposive sampling technique. In the present study only those students were participated who are using Facebook. Intensity of Facebook Usage, life satisfaction scale and subjective happiness scale were emailed to all participants. Online information was received by the researcher. Results showed that Females scored highest on both scales, recording higher levels of Facebook usage and happiness than their male counterparts. Older age group students were found to be more intense Facebook users, more satisfied with their lives and happiest than younger age group students. Positive and significant correlation was observed between Facebook usage, life satisfaction and happiness of older age group college students. The bivariate correlations between the participants groups, happiness and life satisfaction were positive. The study was found to be very useful for college students.

Keywords: Facebook use, life satisfaction, subjective happiness, college students.

In the present modernized society, social media have created popularity among modern youth (Abramson,2011; Kamenetz, 2011) Facebook is becoming a necessary tool in youth's life and has grown increasingly in modern society worldwide. Taking the birth in 2004, Facebook has linked peoples all over the world to communicate, cultivate new friendship for their own taste (Lenhart, 2009).

Researchers have found that among Facebook users, college students are the heavy users (Lampe et al, 2006; DiMicco \&Millen, 2007). Studies indicated that $85 \%$ to $96 \%$ of college students uses Facebook (O’Dell, 2011;Junco et al, 2011;Hargittai, 2008a; Jones and Fox, 2009; Mateney and Borland, 2009). Gonzales et al. (2011) observed that Facebook use enhanced self-esteem of college students and it is linked with positive increase in overall life satisfaction.

\footnotetext{
${ }^{1}$ Assistant Professor, Department of Psychology, Nandini Nagar P. G. College, Nawabganj, Gonda (U.P.) INDIA (c) 2015 I A Srivastava; licensee IJIP. This is an Open Access Research distributed under the terms of the Creative Commons Attribution License (http://creativecommons.org/licenses/by/2.0), which permits unrestricted use, distribution, and reproduction in any Medium, provided the original work is properly cited.
} 


\section{The Effect of Facebook Use on Life Satisfaction and Subjective Happiness of College Students}

Facebook permits to create a profile, display, personal information, upload pictures and interact with friends through messages, gifts and other applications. College students spend almost one to two hours daily on Facebook. It is the most preferred tool for networking among college students.

Studies indicate that the effects of social networking sites (use of Facebook) vary according to users' attributes and internet use functions. Infect social networking like use of Facebook can even enhance the satisfaction and happiness of users who use Facebook for relationship formulation and communication purpose. The result of this type of studies support the stimulation hypothesis, based on which the social network enhances interactions and thus contributes positively to happiness and satisfaction in life.

Ellison et al. (2007) have found that Facebook use was related to bridging, bonding and maintaining social capital which refers to resources received through relationship such as life satisfaction and subjective happiness. On average, college students had between 150 to 200 Facebook friends and generally used the website to communicate to others for building relationship. This indicated that students primarily used Facebook to maintain previously formulated happy networking, rather than creating new network.

Raacke et al (2008; Sheldon 2008; Pempek et al 2009) have noticed that Facebook is used primarily for social connections. Sheldon viewed that students use Facebook to maintain relationship with friends they already knew.

Pempek et al, (2009) asserted that college students used Facebook to communicate information about their satisfaction and happiness. Facebook has also viewed as the "social glue" that assists students to become satisfied with college life.

It appears therefore, that Facebook fulfills its role to support social relationship and to build social connections that enables students to become happier and satisfied with day to day activities.

Subjective happiness is the psychological state of well-being, joy, and contentment (Lyubomirsky, 2001). Subjective happiness has been viewed as a popular conception psychology research and is noted to be a significant part of human life (Doman,2010; Lyubomirsky, 2001).In addition, it is well known that the pursuit of happiness is an important goal for every human being (Lyubomirsky, et al. 2005). Subjective happiness is a construct that is relatively consistent over time and across situations, and it has an impact on how people perceive, interpret, recall, and actually experience life events in a positive or negative way (Lyubomirsky and Tucker, 1998).

Studies have shown that subjective happiness is associated with self-perceptions of well-being, satisfaction with life (Diener, 2000; Suh et al, 1998), satisfying relationships, positive emotions (Diener and Seligman, 2002), emotional intelligence (Extremera, 2005), and self-enhancing bias (Lee and Im,2007). It has also been proved that people, who are subjectively happy think more 


\section{The Effect of Facebook Use on Life Satisfaction and Subjective Happiness of College Students}

positively about themselves (Lee and Im,2007; Campbell, 1981), feel more personal control (Larson, 1989), evaluate recent experiences in their lives as more pleasant (Matlin and Gawron,1979),andtheiremotionalreactionsaremoreintensetopositiveevents, butlesslonglastingtone gativeevents (Seidlitz, 1997).

Life satisfaction is once of human reactions in individual and social. Diener et al. (1992) defined life satisfaction as a personal judgment of property, success and quality of life based on selected criteria of an individual. The concept of life satisfaction is an internal experience which includes positive existence of excitement and lack of negative emotions (Rode, 2005). Internal satisfaction is the result of individual and social growth (Fank et al. 2006).

Life satisfaction refers to a judgmental process in which individuals assess the quality of their lives on the basis of their own unique set of criteria (Shim and Johnson, 1978). A comparison of one's perceived life circumstances with a self-imposed standard or set of standards in presumably made, and to the degree that conditions match these standards, the person reports high life satisfaction. Therefore, life satisfaction is a conscious cognitive judgment of one's life in which the criteria for judgment are up to the person.

Nasirei- Jokar (2008) mentioned the indirect role of hope in the relationship between meaningfulness of life and mental health indices in girls and women and pointed out that this meaningfulness leads to the increase of happiness and life satisfaction. Life satisfaction in adolescents increases as they get older. Relationship with friends is of high importance in adolescents. Having proper relationship with classmate and friends are effective factors in life satisfaction of college students.

Researchers equate life satisfaction with subjective happiness or personal contentment. Existing research highlights that students life satisfaction is determined, in part, by their social ties (Kahneman and Krueger, 2006). Rating of happiness made by one's friends (Leary and Kowalski, 1990), a sociable and extraverted personality (Francis, 1999), frequent interpersonal communication that have positive affect (Diener et al. 1991) and happiness of one's family members (Clore et al.2001) all are correlated to high life satisfaction and happiness.

Extending this view, it could be expected that people who actively participate in Facebook are more likely to experience connectedness and feel happier (Valkenburg, Peter and Schonten, 2006). Facebook can create envy and bitterness because people areexposed to happiness and positive images of their friends. Kavetsos and kontroumpis (2011) analyzed the impact of Facebook use on happiness and found that Facebook is associated with higher level of satisfaction and happiness among college students. Living in a country with high rate of internet users improves life satisfaction as well.

According to a Facebook's statement as on December 31, 2012, it has 1.06 billion monthly active users worldwide including 71 million in India. Facebook has grown so rapidly in such a short period without some pleasurable aspects. 
Kross (2014) conducted a study on 82 adults to examine the effects of Facebook usage on happiness. He observed that Facebook provides an invaluable resources for fulfilling the basic human needs for social connection but rather than enhance well-being.

The present research explores the relationship between Facebook uses, subjective happiness and satisfaction with life among college students by examining two aspects of Facebook usage: Facebook intensity using Ellison et al.'s Facebook intensity scale and also the number of Facebook friends.

\section{METHODS}

\section{Participants:}

Participants were 150 Facebook users between the age of 16 to 30 (75 males and 75 females). They were college students from Lucknow city of Uttar-Pradesh. All participants were classified on the basis of their age in three groups [ $\{1\} 16$ to 20, $\{2\} 21$ to 25, \{3\} 26 to 30]. Only Facebook users were included in the study.

The participants were selected from Facebook using a status update on the researcher's personal profile requesting participation, which included a link to the on line survey. Some participants who completed the survey also posted a link on their own profile; therefore a snowball sample was employed.

\section{Measures:}

\section{Intensity of Facebook Usage:}

Facebook intensity scale developed by Ellison et al. (2007) was used to answer the intensity of Facebook usage and also the number of friends. This scale measures the number of Facebook friends where $1=$ "50 or less", $2=$ " 51 to 100 ”, $3=$ "101 to 150 ", $4=$ " 151 to 200 ", $5=$ " 201 to 250", 6= "251 to 300”, $7=$ "301 to 500”, 8= “501 to $1000 ”, 9=$ "1001 to 5000”, $10=$ "5001 to more". It also measures the time spent on Facebook (1= "less than 10 minutes", $2=$ "10 to 30 minutes", $3=$ "31 to 60 minutes", $4=$ " 1 to 2 hours", $5=$ "2 to 3 hours", 6= "3 hours to more”).The Facebook Intensity Scale has been used frequently in recent Facebook related research, with over 1,500 citations on Google scholar since 2007.

\section{Subjective Happiness Scale:}

Subjective happiness scale developed by Lyubomirsky and Lepper (1999) was used to measures the happiness. There are 4 items to be rated on a 7 point Likert scale (e.g. "In general, I consider myself" on a scale from 1 "not a very happy person” to 7 “a very happy person”). The scores from these statements were averaged to create the variable happiness. 


\section{Life-Satisfaction Scale:}

Life Satisfaction Scale developed by Diener et al. (1985) was used in this study. This scale includes 5 questions with 7 point Likert scale. The alternative absolutely correct is scored 7 while alternative absolutely wrong is scored 1 . The range of scores is between 5 to 35 . This scale has 0.86 reliability.

\section{Demographic Information:}

Other demographic Information was also collected with the help of a questionnaire. This included age, gender and class etc.

\section{Design and Data Analysis:}

A between subject design was used to examine the correlation between variables. The predictor variables measured are Facebook usage and the number of Facebook friends, the criterion variables is happiness and satisfaction with life demographic variables (gender, age) are also examined.

A Pearson R correlation was carried out to investigate the correlation between Facebook usage and happiness and life satisfaction, number of Facebook friends and happiness and Facebook usage to examine the differences in scores between genders for satisfaction with life.

\section{Procedure:}

Participants were selected using on online questionnaire link posted on the researcher's personal Facebook pages of participants who had completed it. All participants took part using their personal computers. All participants were informed about the aim of the study, they completed three sections of the questionnaire; demographic details, Facebook activity. They were asked to select their number of Facebook friends and the approximate time per day spent using the site in the previous week. Happiness and Facebook intensity were measured using concerned measures. Finally they were directed to a debrief page which thanked them for their time and reconfirmed the contact email address.

\section{RESULTS}

\section{Facebook usage and happiness:}

Table 1 shows the mean and standard deviation of all participants' group scores on the Facebook intensity scale and subjective happiness scale. Females scored highest on both scales, recording higher levels of Facebook usage and happiness than their male counterparts. Older age group students were found to be more intense Facebook users than younger age group students. Older age group students were happiest than younger age group students. 
The Effect of Facebook Use on Life Satisfaction and Subjective Happiness of College Students

Table-1: Mean and SD of scores on the Facebook intensity scale and subjective happiness for all participants groups

\begin{tabular}{|l|l|l|l|l|l|l|}
\hline \multirow{2}{*}{ Groups } & \multicolumn{3}{|l|}{ Facebook usage } & \multicolumn{3}{l|}{ Happiness } \\
\cline { 2 - 7 } & Mean & SD & Number & Mean & SD & Number \\
\hline All participants & 3.36 & .85 & 150 & 5.20 & 1.09 & 150 \\
\hline Male & 3.09 & .80 & 75 & 4.97 & 1.15 & 75 \\
\hline Female & 3.29 & .82 & 75 & 5.30 & 1.05 & 75 \\
\hline Age & & & & & & \\
\hline $\mathbf{1 6 - 2 0}$ & 2.91 & .47 & 50 & 4.65 & .49 & 50 \\
\hline $\mathbf{2 1 - 2 5}$ & 3.40 & .90 & 50 & 5.33 & 1.09 & 50 \\
\hline $\mathbf{2 6 - 3 0}$ & 3.50 & .75 & 50 & 5.39 & 1.24 & 50 \\
\hline
\end{tabular}

\section{Facebook usage and satisfaction with life:}

Table 2 shows the means and standard deviation of all participants' group scores on the Facebook intensity scale and life satisfaction scale. Females scored highest on both scales, recording higher levels of Facebook usage and higher satisfaction with their lives than male respondents. It was also noticed that as age of the participants increased their satisfaction with lives also increased in a significant manner, older participants were found to be more satisfied with their lives than younger participants.

Table-2: Mean and SD of scores on the Facebook intensity scale and life satisfaction scale for all participants group

\begin{tabular}{|l|l|l|l|l|l|l|}
\hline \multirow{2}{*}{ Group } & \multicolumn{3}{|l|}{ Facebook usage } & \multicolumn{3}{l|}{ Life satisfaction } \\
\cline { 2 - 7 } & Mean & SD & Number & Mean & SD & Number \\
\hline All participants & 3.36 & .85 & 150 & 26.50 & 6.53 & 150 \\
\hline Male & 3.09 & .80 & 75 & 24.61 & 5.84 & 75 \\
\hline Female & 3.29 & .82 & 75 & 28.32 & 6.71 & 75 \\
\hline Age & & & & & & \\
\hline $\mathbf{1 6 - 2 0}$ & 2.91 & .47 & 50 & 24.50 & 6.41 & 50 \\
\hline $\mathbf{2 1 - 2 5}$ & 3.40 & .90 & 50 & 26.32 & 5.23 & 50 \\
\hline $\mathbf{2 6 - 3 0}$ & 3.50 & .75 & 50 & 28.18 & 5.12 & 50 \\
\hline
\end{tabular}

The result of correlational analysis is presented in table-3: 
Table-3: Correlation between Facebook usage, Happiness and Satisfaction with life

\begin{tabular}{|l|l|l|}
\hline \multirow{2}{*}{ Group } & Correlation \\
\cline { 2 - 3 } & Happiness & Life Satisfaction \\
\hline All participants & 1.08 & 1.09 \\
\hline Male & 0.27 & 0.26 \\
\hline Female & .008 & 0.12 \\
\hline Age & & \\
\hline $\mathbf{1 6 - 2 0}$ & .09 & 0.08 \\
\hline $\mathbf{2 1 - 2 5}$ & 0.49 & 0.51 \\
\hline $\mathbf{2 6 - 3 0}$ & $0.43^{* *}$ & $0.49^{* *}$ \\
\hline
\end{tabular}

**Significant at 0.05level

The result of table 3 indicates that there is positive and significant correlation between Facebook usage and happiness of older age group college students. The correlation between low life satisfaction, Facebook usage, happiness and life satisfaction in all other groups, and indeed on the sample over all were not significant. Over all the result suggest that there exist some correlation between Facebook usage, happiness and life satisfaction, contrary to the previous researches.

The multiple regression analysis was also conducted to evaluate how well the various participants group predicted happiness and satisfaction with life. The predictors were gender and age, while the criterion was happiness and life satisfaction. The linear combination of participants group were not significantly related to happiness, $f(2,150)=1.16, p>0.05$ and life satisfaction, $\mathrm{f}(2,150)=1.17, \mathrm{p}>0.05$. The sample multiple correlation coefficients were .16 and .17 , indicating that approximately $3 \%$ of the variance of happiness and life satisfaction in the sample can be accounted for by the linear combination of the different participant group.

Table 4 presents the relevant strength of the individual predictors. All the bivariate correlations between the participants group, happiness and life satisfaction were positive. On the basis of these results, it can be concluded that the only useful predictor for happiness and life satisfaction amongst the participants studied is gender. 
Table-4: The Bivariate and partial correlation of the predictors with happiness levels and life satisfaction

\begin{tabular}{|l|l|l|l|l|}
\hline & $\begin{array}{l}\text { Correlation } \\
\text { between each } \\
\text { predictors } \\
\text { and happiness }\end{array}$ & $\begin{array}{l}\text { Correlation } \\
\text { between each } \\
\text { predictors } \\
\text { and life } \\
\text { satisfaction }\end{array}$ & $\begin{array}{l}\text { Correlation } \\
\text { between each } \\
\text { predictors and } \\
\text { happiness levels } \\
\text { controlling for } \\
\text { all other } \\
\text { predictors }\end{array}$ & $\begin{array}{l}\text { Correlation } \\
\text { between each } \\
\text { predictors and } \\
\text { life satisfaction } \\
\text { controlling for } \\
\text { all other } \\
\text { predictors }\end{array}$ \\
\hline Gender & .14 & .14 & .14 & .17 \\
\hline Age & & & & .04 \\
\hline $\mathbf{1 6 - 2 0}$ & .19 & .14 & .03 & .06 \\
\hline $\mathbf{2 1 - 2 5}$ & .17 & .16 & .04 & .02 \\
\hline $\mathbf{2 6 - 3 0}$ & .18 & .14 & & \\
\hline
\end{tabular}

Number of Facebook friends, happiness and life satisfaction:

Figure 1, given below, shows the mean number of Facebook friends across all participants group.

Figure-1: Mean number of Facebook friends for all participants group

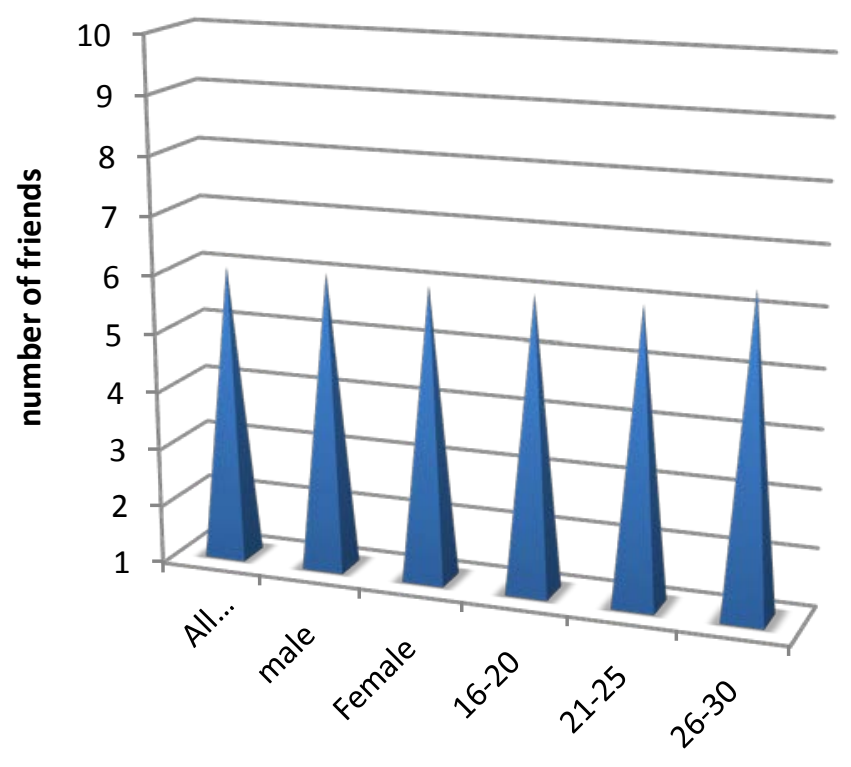

Facebook Friends 
Note-1 $=50$ or less Facebook friends, 2= 51-100 Facebook friends,

3=101-150 Facebook friend,4= 151-200 Facebook friends,

5= 201-250 Facebook friend, 6= 251-300 Facebook friends,

7= 301-500 Facebook friends, $\mathbf{8}=$ 501-1000 Facebook friends,

9= 1001-5000 Facebook friends, 10= 5001- above Facebook friends

The above figure1 shows that over all participants had an average of between 251 to 300 Facebook friends $(m=6.03, \mathrm{SD}=1.99, \mathrm{n}=150)$ with male's having slightly more than female participants $(m=6.08, S D=1.96, n=150 ; m=6.01, S D=2.01, n=75)$. The older age participants had highest number of friends on Facebook $(m=6.42, \mathrm{SD}=1.76, \mathrm{n}=50)$.

A correlational analysis between number of Facebook friends, happiness and life satisfaction is presented in table 5:

Table-5: Correlation between number of Facebook friends, happiness and life satisfaction

\begin{tabular}{|l|l|l|}
\hline \multirow{2}{*}{ Groups } & Correlation \\
\cline { 2 - 4 } & Happiness & Life Satisfaction \\
\hline All participants & $0.64^{* *}$ & $0.66^{*}$ \\
\hline Male & .12 & .14 \\
\hline Female & .18 & .17 \\
\hline Age & & \\
\hline $\mathbf{1 6 - 2 0}$ & .13 & .16 \\
\hline $\mathbf{2 1 - 2 5}$ & .21 & .19 \\
\hline $\mathbf{2 6 - 3 0}$ & $.37 * *$ & $.38^{* *}$ \\
\hline
\end{tabular}

Table 5 indicates that positive and significant relationship were observed between Facebook usage, happiness and life satisfaction, $r=.64, \mathrm{n}=150, \mathrm{r}=.66, \mathrm{n}=150$, older age group participants also showed positive and significant correlation between number of Facebook friends, happiness and life satisfaction, $r=.37, n=50, r=.38, n=50$, other groups also showed positive relationship but their correlations were not significant.

\section{DISCUSSION}

The aim of the present study was to examine the effect of Facebook usage on happiness and life satisfaction of college students, and also to broaden current knowledge in the area by examining these variables through gender and age.

The effects of Facebook usage on happiness was explored using two aspect of interaction with the site, the intensity of usage measured by the Facebook intensity scale and also the number of 


\section{The Effect of Facebook Use on Life Satisfaction and Subjective Happiness of College Students}

Facebook friends. Happiness was measured using subjective happiness scale. The second important variable was life satisfaction and it was measured by life satisfaction scale. 150 participants between the ages of 16 to 30 were selected to examine these aims, over $25 \%$ participants were found who spent an average of 3 hours or more per day on the Facebook site. Females were found to be happier and fully satisfied with life than male participants, also older students were happier and satisfied than younger students.

The results of the present study were consistent with previous research which links using Facebook with a positive influence on users lives, such as the enhancement of happiness (Gonzales and Hancock, 2011) or an increase in overall life satisfaction (Ellison et al, 2007; Vanazuela et al, 2009).

It was mentioned that there will be a link between the number of Facebook friends, happiness and life satisfaction. It was observed in the analysis that this type of link exists. A positive correlation was found for the group as a whole considering these results. It can be argued that the number of Facebook friends is the best indicator of happiness and life satisfaction. This is supported by previous research which studied the effect of Facebook friends (Kaplidon et al, 2011; Demir, 2008). Furthermore the largest proportion of participants selected "I use Facebook to keep in touch with my old friends" on the F/S as their primary reason for using the site in the present research.

Facebook differs somewhat to other social network site in this respect as friends added to the user's social network. Thus it stands to reason that users with more Facebook friends will be happier and satisfied with life, as a relationship already exists with people they have added on the site. This is further supported by only $5.5 \%$ of respondents saying that they use the site to make new friends, compared with the $80 \%$ who used it to keep in touch with old friends. Given this information, it is likely that those with a large number of friends on the site also have a large number of friends off line, and it is possibly this factor that correlation with happiness and life satisfaction is positive (Ryan\& Xenos, 2011).

Research also suggests that people who are involved in online relationship are more willing to communicate in real life (Sheldon, 2008). The results of this study indicate a link between the number of friends and happiness and life satisfaction. This study also supported the previous views that friends are an essential predictor of happiness and satisfaction (De Roiste, 1996).

Present study has certain limitation. First, it is conducted only college students and on certain specific age group. It is important that a wider sample is used particularly in Facebook studies. Furthermore, a detailed analysis of Facebook friends is advised in future research. Facebook privacy setting should be taken into account for future studies. If any aspect of sharing information, or the frequency of doing so is being investigated then it is important to understand who and what users are allowing others in their social network to see. 
REFERENCES:

Abramson,L.(2011).Cansocial networking keep students in school? NPR:MorningEdition,RetrievedJanuary14,2010,from.http://www.npr.org/2011/02/09/133 598049/can-social-networking-keep-students-in-school.

CampbellA. (1981), the sense of well-being in America. New York: Mc Graw-Hill.

Clore, G. L; Wyer, R.S; Jr; Dienes, B; Gasper, K, and Isbell L. M. (2001). Affecting feelings as Facebook: some cognitive consequences. In I. I. Martin and G. L Clore (Ed) theories of mood and cognition: a user's guidebook (27-62) Hillsdale, NJ: Erlbaum.

De Roiste, A. (1996) Sources of worry and happiness in Ireland. The Irish Journal of Psychology 17 (3) 193-212.

Diener E, Seligman M. E. P., (2002).Very happy people, Psychological Science; 13:81-84.

Diener, E. (1985). Subjective well-being. Psychological Bulletin, 95, 542-575.

Diener, E.(2000). Subjective well-being: the science of happiness and a proposal of a national index. American Psychologist; 55:34-43.

Diener, E. (2009). Culture of well-being, Dordrecht, Netherland, springer.

Diener, E.; Emmons, R. A.; Larson, R. J. and Griffin, S. (1985). The satisfaction with life scale. Journal of Personality Assessment, 49, 71-75.

Diener, F. and Larson, R. J. (1992). The subjective experience of emotional well- being. In M. Lewis and J. M. Havilland (Ed) Handbook of emotion (405-415) New York Guilford.

DiMicco JM, Millen D R. (2007). Identity management: Multiple presentations of self in Facebook. Paper presented at the international ACM Conference, Sanibel Island, Florida.

doi:10.1145/1316624.1316682

Doman, M.M. (2010). Compassion fatigue, burnout, compassion Satisfaction, and subjective happiness in mental health pro-videos. Unpublished doctoral dissertation, University of La Verne,

Ellison, N.B., Steinfield, C., Lampe C. (2007). The benefits of Facebook “friends” social capital and college students' use of online social network sites. Journal of Computer- Mediated Communication, 12, 1143-1168.

Extremera N, Duran A, Rey L., (2005).La inteligencia emotional percibi day suinfluenciasboreal satisfactions vital, lafeli-cidad subjetivayel “engagement, entrabajadoresdecen -trospara personas condis capacidad intellectual. Ansiedady Estre 's; 11:63-73.

Francis, L. J. (1999). Happiness is the thing called stable extraversion: A further examination of the relationship between the Oxford happiness inventory and Eysenck's dimensional model of person gender, personality and individual's differences, 26, 5-11.

Gonzales, A .L.\& Hancock, J. T. (2011). Mirror, mirror on my Facebook wall: Effects of exposure to Facebook self-esteem. Cyber psychology, Behavior\& Social Networking, 14, (1-2)79-83.

Hargittai, E.(2008a).Who se space? Differences among users and nonusers of social network sites. Journal of Computer-Mediated Communication,13(1), 276-297. 
Jones, S. \& Fox, S. (2009). Generationsonlinein2009.Datamemo.Washington, DC: Pew Internet and American Life Project. Retrieved March 7, 2010, from. http://www.pewinternet.org/w/media//Files/Reports/2009/PIP_Generations_2009.pdf.

Junco R, Heiberger G, Loken E (2011). The effect of Twitter on college student engagement and grades. Journal of Computer Assisted Learning; 27(2):119-132.

Kahneman, D. and Krueger A. B. (2006). Developments in the measurement of subjective wellbeing. Journal of Economic Perspective, 20, (1), 3-24.

Kamenetz,A.(2011).Gates Foundation bets on Facebook app to help kids graduate. FastCompany,RetrievedFebruary14,2011, from. http://www.fastcompany.com/1725665/gates-foundation-bets-on-facebook-app-to-helpkids-graduate.

Kaplidon, M,; Costin, D. and Morris, J. (2011). The relationship between Facebook and the wellbeing of undergraduate college students. Cyber Psychology, Behavior and Social Networking, 14 (4) 183- 189.

Kincaid, J. (2009) Facebook prototype measures gross national happiness, confirms that we had Mondays, Tech church, Retrieved Feb 18, 2012 from- http//www.techchurch.com

Kross, E. (2014). Effects of Facebook uses on happiness, Scientific Journal of PLOS.

Lampe C, Ellison N, Steinfield C (2006). A Facebook in the crowd: Social searching vs. social browsing. Proceedings of the 20th Anniversary Conference on Computer Supported Cooperative Work (pp. 167-170). New York: ACM Press.

LarsonR. (1989). Is feeling' 'in control' 'related to happiness in daily life? PsychologicalReports64:775-784.

Leary, M. R. and Kowalski, R. M. (1990). Impression management: A literature review and two component model. Psychological Bulletin, 107, 34-47.

Lee, J. Y., Im, G. S., (2007). Self-enhancing bias in personality, subjective happiness, and perception of life events: are applications in a Korean aged sample. A gingand Mental Health; 11:57-60.

Lyubomirsky, S. (2001) Why are some people happierth anothers? The role of cognitive and motivational processes in well-being. American Psychologist; 56:239-249.

Lyubomirsky, S.; King, L, and Diener, E, (2005). The benefit of frequent positive affect: does happiness lead to success? Psychological Bulletin, 131, 803-855.

Lyubomirsky, S.; Sheldon, K.M.; Schkade, D. (2005). Pursuing happiness: the architecture of sustainable change. Review of General Psychology;9:111-131.

Lyubomirsky, S.; Tucker, K.L. (1998). Implications of individual differences in subjective happiness for perceiving, interpreting, and thinking about life events. Motivation and Emotion; 22:155-186.

Matlin M W, GawronVJ (1979).Individual differences in Pollyan- Naism. Journal of Personality Assessment;43:411-412.

Matney,M.,\&Borland,K.(2009).Facebook,blogs,tweets:howstaffandunits can use social networking to enhance student learning, Presentation at the annual meeting of the National Association for Student Personnel Administrators, Seattle, WA. 
Nasirei, H. \& Jokar, B, (2008). Meaningfulness of life hope, life satisfaction and mental health in women. Journal of women research 6 (2) 157-176.

O’Dell J. (2011). For students, what is the Facebook effect on grades? [Internet] Retrieved July 12, 2012, from

http://mashable.com/2011/04/27/facebook-effect-students/

Pempek T, Yermolayeva Y, Carvert S (2009). College students' social networking experiences on Facebook. Journal of Applied Developmental Psychology; 30:227-38.

Raacke J, Bonds Raacke J (2008). My Space and Facebook: Applying the uses and gratifications theory to exploring friend-networking sites. Cyber Psychology \& Behavior; 11:169-74.

Ryan, T., and Xenos, S., (2011) who uses Facebook? An investigation into the relationship between the big five, shyness, narcissism, loneliness, and Facebook usage. Computers in human behavior, 27 (5) 1658-1664.

Seidlitz L, Wryer RS, Diener E (1997). Cognitive correlates of subjective well-being: the processing of valences life events by happy and unhappy persons. Journal of Research in Personality; 31:240-256.

Seligman, M.E.P. (2002).Authentic happiness: using the new positive psychology to your potential for lasting fulfillment. New York: Farce press/Simon and Schuster.

Sheldon, P. (2008). The relationship between unwillingness to communicate and students' Facebook use. Journal of Media Psychology: theories, methods and application 20 (2) 6775.

Shin, D. C. and Johnson, D. M. (1978). A vowed happiness as an overall assessment of the quality of life. Social indicators research, 5, 475-492.

SuhE,DienerE,OishiS,etal.(1998).Theshiftingbasisoflifesatisfaction judgments across cultures: emotions versus norms. Journal of Personality and Social Psychology; 74:482-493.

Valenzuela, S., Park N., Kee, K. (2009). Is there social capital in the social network site? Facebook use and college students' life satisfaction, trust and participation, Journal of Computer Mediated Communication. 4, 875-901.

Valkenburg, P. M.; Peter, J. and Schonten, A. P. (2006). Friend networking sites and their relationship to adolescent's well-being and social self-esteem. Cyber Psychology and Behavior, 9, 584-590. 